\title{
Efficacy of Reuterin and Bacteriocins Nisin and Pediocin in the Preservation of Raw Milk from Dairy Farms
}

\author{
Nirmal Kumar®®, \\ Vinay Kumar ${ }^{1}{ }^{\circ}$, \\ Syed Mohsin Waheed ${ }^{1 *}$ (D) \\ and Diwas Pradhan ${ }^{2 *}$ \\ 'Department of Biotechnology, \\ Graphic Era (Deemed to be \\ University), 566/6 Bell Road, Society \\ Area, Clement Town, 248002 \\ Dehradun, Uttarakhand, India \\ 2Dairy Microbiology Division, ICAR- \\ National Dairy Research Institute, GT \\ Rd, 132001 Karnal, Haryana, India
}

Received: 2 April 2020 Accepted: 27 September 2020

${ }^{*}$ Corresponding authors:

Phone: +911842259169

E-mail:zawidprd@gmail.com

Phone: +919811968019

E-mail:syedmohsinwaheed@yahoo.com

\section{SUMMARY}

Research background. In the current scenario of milk production in developing and developed countries, several factors influence the shelf-life of raw milk and add significant numbers of microbial contaminants that drastically lower the initial microbial quality leading to milk spoilage by the time it reaches the processing units.

Experimental approach. The present study was undertaken to investigate the biopreservative efficacy of reuterin system along with different combinations of bacteriocins in controlling the initial microflora of raw milk at farm level. Lactobacillus reuteri strain LR47, having effective antimicrobial activity, was shortlisted from our previous study and further characterized for reuterin production and tested in raw milk system.

Results and conclusions. Preliminary testing of the cell-free supernatant from L. reuteri LR47 demonstrated significant growth inhibition of the majority of the tested bacterial indicators of milk spoilage. Further genetic analysis of the L. reuteri LR47 revealed the presence of two genes ( $p d u C$ and $d h a B$ ) involved in the utilization of glycerol to produce reuterin via two different pathways. The strain LR47 was also found to possess comparatively higher capacity to convert glycerol into reuterin when checked through colourimetric assay. In the raw milk biopreservation experiment with reuterin alone or in combination with bacteriocins, the highest level of growth suppression in the total bacterial load and coliform counts was observed in the sample that was treated with a combination of reuterin, nisin and pediocin. The treatment combining these three natural biopreservatives at specific concentrations was able to maintain the initial microbial quality and extend the shelf-life of raw milk by $6 \mathrm{~h}$ at $37^{\circ} \mathrm{C}$ based on the microbial counts and physicochemical properties, viz. pH and titratable acidity. In conclusion, the results confirm that the use of reuterin in combination with bacteriocins is a promising approach for temporary control of the raw milk microflora and extension of its shelf-life until further processing.

Novelty and scientific contribution. This study demonstrates for the first time the use of reuterin for the extension of shelf-life of raw milk as an alternative treatment method.

Key words: reuterin, bacteriocins, raw milk, milk biopreservation, Lactobacillus reuteri

\section{INTRODUCTION}

Milk is an important component of the diet of a vast population. It ranks high among other foods and is considered as the perfect food for humans from birth to old age. It not only has good sensory properties, but it also fulfils the nutrient requirements of the body for healthy growth. It could also prevent or reduce risk of many nutritional deficiency diseases (1). Milk, due to its unique composition and growth-promoting properties, is a favourable growth medium for many microorganisms responsible for milk-borne diseases and its spoilage (2), and for the same reason, it is highly perishable item. Poor handling of milk may affect public health and cause economic loss, thus it requires hygienic vigilance and monitoring throughout the chain (3). Milk from healthy cows is virtually sterile before leaving the udder (4). Number and type of bacteria that might contaminate milk immediately after milking depend on the cleanliness and hygienic practices of the farmworkers, hygiene of milking equipment and dairy farm environment, weaknesses in the cold chain during production process, transportation, storage, etc. (5). 
The presence of high microbial load in the raw milk is a serious problem because of the ability of bacteria to cause milk-borne diseases and reduce the shelf-life of milk. Furthermore, contaminated milk is also responsible for spreading milk-borne epidemics to humans. According to World Health Organization (WHO) reports, raw milk is implicated in $39.1 \%$ of the total bacterial foodborne outbreaks (6). In fact, over the past few decades, the number of reported foodborne disease outbreaks have significantly increased, which is attributed to raw milk (7). Microbial contamination of milk is responsible for economic losses at various stages of the milk production chain. For instance, early spoilage of milk in developing countries was responsible for the loss of $20 \%$ of milk production, resulting in a 12 US\$ loss per month to each dairy farmer (8). According to the Food and Agriculture Organization (FAO) report, 90 million US\$ worth of milk is lost each year in East Africa and Near East during production and distribution before it even reaches a store (9). As per the 2010 US Department of Agriculture data, 17 billion pounds of milk, or $32 \%$ of total supply, is lost in a year because of milk spoilage (10). Moreover, a study carried out in the North West of Cameroon showed that each farmer loses $1 \mathrm{~L}$ of milk every day because of high microbial contamination of raw milk (8). To overcome this economic distress, both developing and developed countries are experimenting with different approaches to control the microbial load to prevent loss of raw milk at the farm level. Natural antimicrobial compounds are an attractive, safe and cost-effective alternative to prevent milk wastage. However, information available on the biopreservation of raw milk using natural antimicrobial compounds is very limited.

Metabolites of lactic acid bacteria (LAB) are used to improve the safety and extend the shelf-life of different dairy products. Interest in the LAB metabolites has increased exponentially in the last few years. Many different bacteriocins and their combinations with other antimicrobial compounds have been tried to inactivate milk-borne pathogens or spoilage microorganisms with the aim to preserve milk and its products (11). Bacteriocins produced by $L A B$ have antibacterial activity and contain generally recognized as safe (GRAS) compounds (12). Thus, they are increasingly used as natural food preservatives. Nisin and pediocin are bacteriocins that are now available commercially under the name Nisaplin ${ }^{\mathrm{TM}}$ (13) and Alta $2341^{\mathrm{TM}}$ (14), respectively. However, most bacteriocins have rather small spectrum of activity, being active mainly against Gram-positive bacteria (15). Hence, many researchers have attempted to incorporate bacteriocins along with other treatments to broaden their activity, using the concept of hurdle technology for controlling spoilage and pathogenic microorganisms in many food items. Some studies have shown synergistic activity of bacteriocins (16) and their combinations with other antimicrobial agents such as reuterin (17). Despite the strong antimicrobial activity of many LAB metabolites, no sufficient studies have been conducted to maintain the microbial quality of raw milk, particularly at dairy farm level.
Lactobacillus reuteri found in the gastrointestinal (GI) tract of humans and many other animals is one of the important species of lactobacilli (18). L. reuteri is known to be a natural component of human milk (19) and is also found in fermented foods (20). The strains of $L$. reuteri possess a unique property of anaerobically converting glycerol into a potent, broad-spectrum antimicrobial substance, termed 3-hydroxypropionaldehyde (3-HPA), which is commonly known as reuterin (21). Reuterin is an aldehyde that exhibits a wide range of antimicrobial activity against foodborne pathogens and spoilage microorganisms (22). It has a high potential as a food biopreservative since it is water-soluble, resists degradation by proteolytic and lipolytic enzymes, and withstands a broad range of $\mathrm{pH}$ and temperature conditions (23). The antimicrobial efficacy of reuterin has been demonstrated against many common foodborne spoilage and pathogenic organisms such as Staphylococcus aureus, Escherichia coli, Listeria monocytogenes, Salmonella Typhi, Enterococcus feacalis and Pseudomonas aeruginosa (24). Reuterin has a wider range of antimicrobial activity than bacteriocins and other non-bacteriocin antimicrobial compounds (25). Reuterin and nisin in combination act synergistically against $L$. monocytogenes and additively against $S$. aureus in milk (26). Reuterin, alone or in combination with nisin and lactoperoxidase system (LPS), exhibited inhibitory activity against $E$. coli $0157: \mathrm{H} 7$, S. enterica, C. jejuni, A. hydrophila and Y. enterocolitica in refrigerated milk. The combination of monolaurin and nisin has been found to be active against bacilli in milk; in particular, the inhibition of $B$. licheniformis by both antimicrobial substances increased with increasing $\mathrm{pH}$ when they were added simultaneously to milk (27). In addition, the combination of both compounds successfully exerted a bactericidal effect against different Bacillus species in skimmed milk, and also inhibited their regrowth and sporulation (28). The combination of LPS and nisin had a synergistic and long-lasting inhibitory effect on L. monocytogenes in reconstituted skimmed milk and, also, its effectiveness did not depend on $\mathrm{pH}$ (29). Therefore, the incorporation of reuterin and its combination with other bacteriocins in milk and milk products offers a superior alternative for improving the safety, quality, and shelf-life of milk along with the elimination of chemical preservatives. Addition of antimicrobial compounds to raw milk may help in resolving shelf-life problems caused by inadequate refrigeration/absence of cooling facilities, long-distance transport under hot weather conditions, etc. (23). Thus, the present work investigates the preventive role of reuterin in raw milk spoilage under tropical conditions where temperatures above $30^{\circ} \mathrm{C}$ are normally prevalent during summers. Therefore, all experiments were conducted at $37^{\circ} \mathrm{C}$. Until now, no such study has been conducted on the preservation of raw milk using wide-spectrum antimicrobial compounds and their combination with other bacteriocins. Hence, the current study aims to explore the possibility of applying an antimicrobial mix with reuterin as the main additive to extend the shelf-life of raw milk and reduce the probability of milk-borne pathogenesis. 


\section{MATERIALS AND METHODS}

\section{Bacterial strains and culture conditions}

Lactobacillus reuteri ATCC 55730, obtained from BioGaia, Stockholm, Sweden, was used as a reference strain and the test strain, $L$. reuteri LR47 was selected from our previous study (30). The bacterial indicator strains (obtained from an in-house lab culture collection) Escherichia coli K12, Listeria monocytogenes ATCC 13932, Enterococcus faecalis NCDC 135, Serratia marcescens ATCC 13880, Salmonella Typhi NCDC 113, Yersinia enterocolitica ATCC 130715, Klebsiella pneumoniae NCDC 138 and Pediococcus acidilactici LB42 were used for the antibacterial activity testing of $L$. reuteri LR47 supernatant. All the bacterial cultures (excluding P. acidilactici LB42) were grown in brain heart infusion broth (BHI, HiMedia, Mumbai, India), while $P$. acidilactici LB42 and L. reuteri strains were grown in de Man, Rogosa and Sharpe broth (MRS; HiMedia, Mumbai, India) at $37^{\circ} \mathrm{C}$ for $24-48 \mathrm{~h}$. The bacterial strains were maintained as $15 \%$ glycerol stock cultures at $-20^{\circ} \mathrm{C}$ in $\mathrm{BHI}$ and MRS broths. The organisms were propagated twice before their use in the experiments.

\section{Preparation of cell-free supernatants of L. reuteri LR47}

Cell-free supernatants (CFS) of $L$. reuteri LR47 were prepared according to the method described by Lüthi-Peng et al. (31). A single colony with typical morphology (small pinpointed and creamy white colony) from the MRS agar plates was picked and inoculated into MRS broth and incubated anaerobically (gas pack system, HiMedia) at $37{ }^{\circ} \mathrm{C}$ for $20 \mathrm{~h}$. After incubation, the culture was centrifuged (Precision Biotech Instruments Pvt. Ltd., Delhi, India) at $4000 \times g$ and $4{ }^{\circ} \mathrm{C}$ for $10 \mathrm{~min}$. The supernatant was filter-sterilised through a 0.22- $\mu \mathrm{m}$ syringe filter (Millipore, New Delhi, India) to remove any remaining cells. The cell pellet was used for secondary fermentation to prepare a suspension of MRS supplemented with glycerol (360 mM). The supernatant obtained from secondary fermentation of MRS with glycerol was designated MRS-Gly, while the supernatant derived from MRS broth was designated MRSB. Finally, the $\mathrm{pH}$ values of the above supernatants were determined using a portable $\mathrm{pH}$ meter (Orion Star ${ }^{\text {TM }}$ A111; Thermo Fisher Scientific, Waltham, MA, USA). The $\mathrm{pH}$ of the supernatants was adjusted from $\mathrm{pH}=4.6$ to 6.5 (in order to eliminate the cause of microbial death due to acidic $\mathrm{pH}$ ) using $0.1 \mathrm{M}$ sodium hydroxide at room temperature prior to testing their antimicrobial activity.

\section{Antibacterial activity of L. reuteri LR47 supernatant}

Antibacterial activity of $L$. reuteri LR47 CFS was previously tested in our study (30) using agar well diffusion method (32). In this study, we used the microtiter plate method to test the antibacterial activity of the CFS. An aliquot of $20 \mu \mathrm{L}$ of CFS was added, in triplicate, into $180 \mu \mathrm{L}$ of BHI broth containing $10^{6} \mathrm{CFU} / \mathrm{mL}$ of each pathogen, and incubated at $37^{\circ} \mathrm{C}$ for $18 \mathrm{~h}$. Negative control contained pathogen cultures only, while positive control contained commercial antibiotics $(\gamma$ (ampicillin) $=100 \mathrm{mg} / \mathrm{mL}$ as stock solution; Sigma-Aldrich, St. Louis, MO, USA) instead of CFS. The inhibition of indicator strains was quantitatively determined by measuring the absorbance $(A)$ (Spectrostar Nano BMG Labtech, Ortenberg, Germany) at $620 \mathrm{~nm}$, in comparison with the control. The percentage of inhibition was calculated as follows:

$$
\text { Inhibition }=\left(\frac{A(\text { control })-A(\text { sample })}{A(\text { control })}\right) \cdot 100
$$

\section{$P C R$ detection of reuterin-producing $p d u C$ and dhaB genes in L. reuteri LR47}

PCR was conducted using genomic DNA of $L$. reuteri LR47 to detect the presence of $d h a B$ (part of dha gene operon) and $p d u C$ (gene coding for large fragment of $g d h$ protein) genes, responsible for conversion of glycerol into reuterin, using DHAB1 (5'-AACTACGATAACATGTTTGC-'3), DHAB7 (5'-CCTTCTTCTTCAATTCCGGCA-'3) and pduCF (5'-CCTGAAGTAAAYCGCATCTT-'3), pduCR (5'-GAAACYATTTCAGTTTATGG-'3) primer pair as per the method described by Versalovic et al. (33) and Walter (34), respectively. The resulting PCR products were separated and visualized using standard agarose gel electrophoresis.

\section{Colourimetric assay for reuterin and glycerol quantification}

CFSs (MRS-Gly) of three L. reuteri strains (L. reuteri LR47, L. reuteri LR11 and L. reuteri LR 49) were assayed to quantitatively determine glycerol utilisation and the resulting concentration of reuterin present in the CFS. Reuterin and glycerol concentrations were determined, in triplicate, using a colourimetric method adapted from Spagnola (35). Briefly, an aliquot of $330 \mu \mathrm{L}$ of CFS (MRS-Gly) from each bacterium was mixed with $225 \mu \mathrm{L}$ of $10 \mathrm{mM}$ tryptophan (dissolved in $0.05 \mathrm{M} \mathrm{HCl}$ ) and $150 \mu \mathrm{L}$ of $95 \%$ ethanol. Each mixture was incubated at $40^{\circ} \mathrm{C}$ for $50 \mathrm{~min}$ and the absorbance was measured at $A_{560 \mathrm{~nm}}$ using spectrophotometer microplate reader (Spectrostar Nano BMG Labtech, Ortenberg, Germany). The reuterin concentration was calculated by comparing the absorbance of the samples with a standard curve of acrolein, assuming that $1 \mathrm{~mol}$ of reuterin was dehydrated to $1 \mathrm{~mol}$ of acrolein that reacted with tryptophan in the presence of $\mathrm{HCl}$.

\section{Determination of L. reuteri LR47 cell-free supernatant activity}

The activity of $L$. reuteri LR47 CFS was quantified by minimum inhibitory concentration (MIC) assay using a microtiter plate against $E$. coli $\mathrm{K} 12$ as described by Chung et al. (36). Overnight culture of E. coli $\mathrm{K} 12$ was harvested, washed twice with phosphate buffer $(\mathrm{pH}=7.2,50 \mathrm{mM})$, suspended in the same buffer, and diluted to an $A_{620 \mathrm{~nm}}$ of 0.2 measured using a spectrophotometer (Spectrostar Nano BMG Labtech). This suspension was diluted 1:10, which corresponds to about $10^{6} \mathrm{CFU} /$ $\mathrm{mL}$. The diluted suspension $(0.1 \mathrm{~mL})$ was used to inoculate 0.2 $\mathrm{mL}$ of serial dilutions of CFS in Müller-Hinton medium (HiMedia). The microtiter plate was incubated at $37^{\circ} \mathrm{C}$ for $12 \mathrm{~h}$ and 
then the growth of indicator strain E. coli K12 was examined. The unit of the CFS activity was defined as the reciprocal of the highest dilution that did not permit visible growth of the indicator strain and expressed in arbitrary unit (AU). Accordingly, the activity of the CFS was calculated to be $1600 \mathrm{AU} / \mathrm{mL}$.

\section{Measurement of pediocin and nisin activities}

Pediocin was prepared by inoculating active cultures of pediocin-producing Pediococcus pentosaceus 34 (37) in 100-mL aliquots of MRS broth and incubated at $37{ }^{\circ} \mathrm{C}$ for $24 \mathrm{~h}$. CFS was prepared by centrifugation of the culture in a refrigerated centrifuge (Precision Biotech Instruments Pvt. Ltd.) at $4000 \times g$ for $10 \mathrm{~min}$. The supernatant was filter-sterilized by passing through $0.22-\mu \mathrm{m}$ pore size membrane filter after neutralization. Pediocin activity was quantified by the MIC method against Pediococcus acidilactici LB42 as described by Kaur et al. (38) using microtiter plates. Nisin was procured from Sigma-Aldrich. Stock solutions of nisin $(1000 \mathrm{lU} / \mathrm{mL})$ were prepared in $0.02 \mathrm{M} \mathrm{HCl}$ and stored at $-40^{\circ} \mathrm{C}$. The nisin stock solution was diluted prior to use in experiments.

\section{Collection of raw cow's milk samples and experimental design}

Raw milk samples of Bos taurus (Sahiwal breed) were obtained from the Experimental Dairy plant of ICAR-NDRI, Karnal, India. All samples were collected in the morning. After the collection of samples, it was immediately transported to the laboratory in a tightly closed container placed in an ice box. At the start of each experiment, a volume of $100 \mathrm{~mL}$ of raw milk was aliquoted in 14 sterile screw-cap glass bottles as per experimental design. Each sample was marked with the type of antimicrobial treatment to be given. Antimicrobial compounds in different combinations and different activities (Table 1) were added concomitantly to the respective sample bottles. Milk sample without the addition of antimicrobials

Table 1. Activity of reuterin (R) in combination with nisin (N) and pe$\operatorname{diocin}(\mathrm{P})$

\begin{tabular}{lccc} 
Treatment & $\begin{array}{c}\text { Reuterin } \\
\text { activity/ } \\
\text { (AU/mL) }\end{array}$ & $\begin{array}{c}\text { Nisin activity/ } \\
(\mathrm{IU} / \mathrm{mL})\end{array}$ & $\begin{array}{l}\text { Pediocin } \\
\text { activity/ } \\
\text { (AU/mL) }\end{array}$ \\
Control & 0 & 0 & 0 \\
R1 & 150 & 0 & 0 \\
$\mathrm{~N} 1$ & 0 & 100 & 0 \\
$\mathrm{P} 1$ & 0 & 0 & 2185 \\
$\mathrm{R} 1+\mathrm{N} 1$ & 150 & 100 & 0 \\
$\mathrm{R} 1+\mathrm{P} 1$ & 100 & 0 & 2185 \\
$\mathrm{R} 1+\mathrm{N} 1+\mathrm{P} 1$ & 150 & 100 & 2185 \\
$\mathrm{R} 2+\mathrm{N} 2+\mathrm{P} 2$ & 16 & 20 & 600 \\
R1+N2+P2 & 150 & 20 & 600 \\
R2+N1+P1 & 16 & 100 & 2185 \\
R1+N1+P2 & 150 & 100 & 600 \\
R2+N2+P1 & 16 & 20 & 2185 \\
R2+N1+P2 & 16 & 100 & 600 \\
R1+N2+P1 & 100 & 20 & 2185 \\
\hline
\end{tabular}

served as a control. All the untreated and treated milk samples were incubated at $37^{\circ} \mathrm{C}$ for $9 \mathrm{~h}$ and parameters were measured after 3, 6 and $9 \mathrm{~h}$ of experiment.

\section{Chemical and bacteriological analyses}

The analysed chemical parameters of the raw milk samples were $\mathrm{pH}$ and titratable acidity (TA). The $\mathrm{pH}$ was measured using a digital $\mathrm{pH}$ meter (Orion Star ${ }^{\mathrm{TM}} \mathrm{A} 111$; Thermo Fisher Scientific) and the TA was determined by titration method (39) at different time intervals (0, 3, 6 and 9 h). Each sample was measured in triplicate. Total plate count (TPC) and coliform counts were also tested simultaneously by the sample dilution pour plate method. Briefly, tenfold serial dilutions of samples were made up to volume fraction of $10^{-7}$ in normal saline solutions $(0.85 \%)$. A volume of $1 \mathrm{~mL}$ of milk sample was diluted in a series of normal saline solutions ( $9 \mathrm{~mL}$ of saline down to $10^{-8}$ ) and 1-mL aliquots of milk in the saline solution from appropriate volume fraction dilutions: $10^{-1}, 10^{-3}$ or $10^{-5}$ for coliform count, and $10^{-3}, 10^{-5}$ or $10^{-7}$ for TPC were transferred to Petri dishes. Samples were plated in triplicates, using pour plate technique. Nutrient agar medium (HiMedia) was used for the TPC, while violet red bile agar (HiMedia) was used for counting coliforms incubated at $37^{\circ} \mathrm{C}$. After incubation, plates containing 30 to 300 colonies were selected for screening and results were expressed as log CFU/mL.

\section{Statistical analysis}

The data obtained in this study are presented as mean value \pm standard deviation (S.D.) and analyzed statistically with the GraphPad Prism software (40). Microbiological counts were converted to log CFU/mL and the statistical significance among different antimicrobials and their combination in milk system was compared by two-way analysis of variance (ANOVA) followed by Tukey's test and considered significant at $\mathrm{p} \leq 0.01$.

\section{RESULTS AND DISCUSSION}

\section{Antibacterial activity of L. reuteri LR47 CFS against selected indicator strains}

Many wild-type variants of Lactobacillus reuteri have the ability to produce reuterin from anaerobic conversion of glycerol (22). Reuterin is a potent and a wide-spectrum antimicrobial agent that suppresses various kinds of bacteria, fungi, protozoa, etc. (21). However, many inherent genetic factors as well as other external factors influence reuterin production (41). Hence, efforts are mainly focused on bioprospecting high reuterin-producing $L$. reuteri strains from different niches. We selected $L$. reuteri strain LR47 from our previous study (30), which had shown highest antimicrobial activity during the initial screening, which was further tested against eight different bacterial indicators that included important food pathogens. Both, CFS before $(\mathrm{pH}=4.5)$ and after the adjustment of the $\mathrm{pH}$ value $(\mathrm{pH}=6.5)$ derived from MRSB and MRS-Gly were used to test the antimicrobial 
activity. Antimicrobial activity was observed in both MRS-Gly and MRSB (Fig. 1); however, inhibitory effect of MRSB was very low or insignificant at $\mathrm{pH}=6.5$ (Fig. 1a). L. reuteri, being a $L A B$, secretes organic acids such as lactic acid, acetic acid, etc. as primary fermentation products and many others as secondary metabolites (15) that have been reported to produce strong antimicrobial activity, particularly in a relatively low $\mathrm{pH}$ environment, which may have contributed to the antimicrobial activity observed in the MRSB. However, antimicrobial activity could not be replicated at $\mathrm{pH}=6.5$. On the other hand, CFS ( $\mathrm{pH}=6.5$ ) from MRS-Gly exhibited strong antimicrobial activity against the majority of indicator strains. It was able to strongly inhibit both Gram-negative and Gram-positive bacterial indicators. The activity observed in this case can be attributed to reuterin, since it acts as an antimicrobial agent against a wide range of bacterial targets at different $\mathrm{pH}$ values including neutral $\mathrm{pH}$ (42), contrary to organic acids and bacteriocins that are effective only against a limited number of bacterial targets and often lose their potential at an altered $\mathrm{pH}$. However, reuterin did not have any significant inhibitory effect against $E$. faecalis and $P$. acidilactici. This is not surprising as it has been reported that

a)

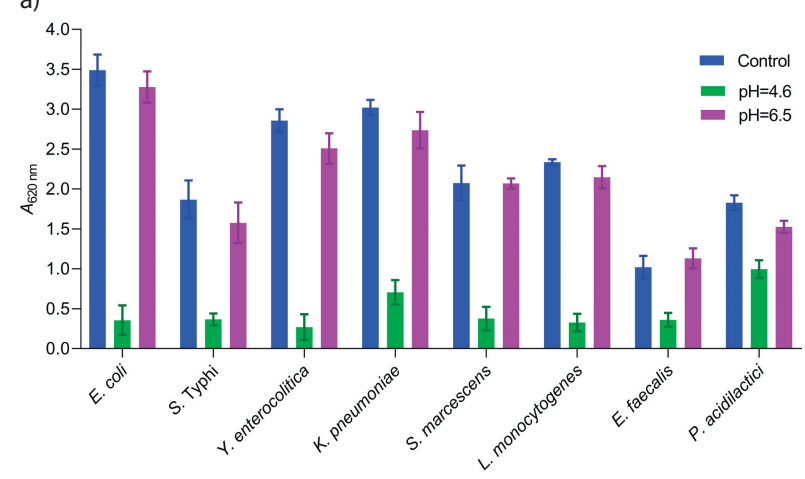

b)

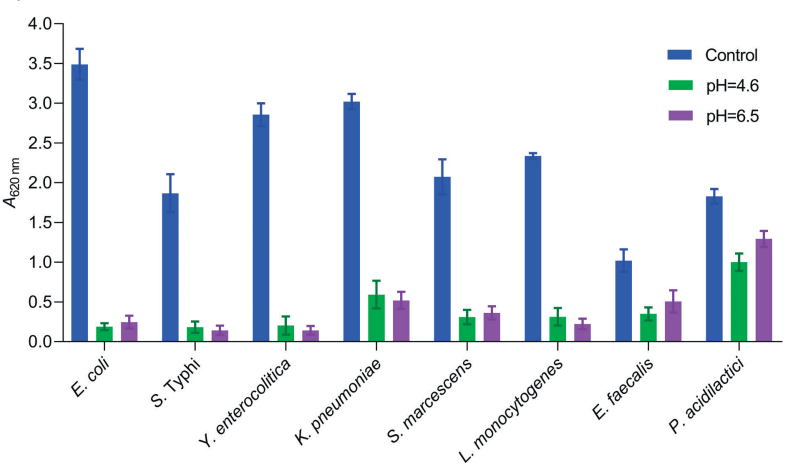

Fig. 1. Indicator strains cocultured with Lactobacillus reuteri LR47 cell-free supernatant (both MRSB and MRS-Gly) and tested for inhibitory effects. The growth of each pathogen was determined by measuring $A_{620 \mathrm{~nm}}$ after $18 \mathrm{~h}$ of incubation at $37^{\circ} \mathrm{C}$ : a) inhibitory effect of MRSB with $(\mathrm{pH}=6.5)$ and without $(\mathrm{pH}=4.6) \mathrm{pH}$ adjustment, and $\mathrm{b})$ inhibitory effect of MRS-Gly with and without $\mathrm{pH}$ adjustment. Untreated controls contained pathogen cultures only. Bar values are presented as calculated mean value of measurements at $A_{620 \mathrm{~nm}}(N=3)$ with standard error of the mean shown as vertical bars reuterin affects lactic acid bacteria to a lesser degree, and a relatively higher concentration of reuterin is required to inhibit the growth of $L A B(21)$.

\section{PCR detection of reuterin-producing genes in L. reuteri LR47}

Few bacterial strains have the metabolic capacity to utilize glycerol and produce reuterin. Among them are L. reuteri strains, which possess all the necessary genes for bioconversion of glycerol into reuterin. Glycerol dehydratase and diol dehydratase are two discrete isofunctional enzymes, which catalyse the reaction of glycerol dehydration to reuterin by two independent pathways $(41,43)$. The structural genes of the glycerol dehydratase ( $d h a B C E)$ of $L$. reuteri are part of the dha regulon and its expression is induced under anaerobic conditions in the presence of glycerol. On the other hand, diol dehydratase genes of $L$. reuteri are part of $p d u$ operon ( $p d u C D E$ ) which also contains genes for glycerol utilization. Glycerol, a second substrate of $p d u C D E$, is transformed into an intermediate compound (reuterin), which can be further metabolized to 1,3-propanediol or 3-hydroxypropionate. Earlier, Schaefer et al. (44) demonstrated the elimination of reuterin production by disrupting/deleting the $p d u C$ gene in $L$. reuteri strains ATCC 23272 and confirming the role of $p d u C$ gene in reuterin production. Therefore, we also attempted to check the presence of either one or both genes in L. reuteri LR47 by PCR assay. The PCR results showed a positive amplification of both genes, viz. pduC (105 bp) and dha (900 bp) in L. reuteri LR47 (data not shown), which confirmed that this strain possessed these genes and molecular set-up to drive the conversion of glycerol to reuterin.

\section{Colourimetric estimation of reuterin production in L. reuteri strains}

To confirm and augment the genetic screening results, we also performed the colourimetric estimation of reuterin production in CFS of $L$. reuteri LR47. Colourimetric estimation of reuterin was performed to determine the levels of reuterin produced among different strains of $L$. reuteri ( $L$. reuteri LR47, L. reuteri LR49 and L. reuteri LR11) (30). Initial and final concentrations of reuterin were determined and compared within and among different strains used in the study. Also, the amount of utilised glycerol was determined and compared with the respective supernatant of these three L. reuteri strains. It is evident from Fig. 2 that reuterin production in L. reuteri LR47 was significantly higher than in the other two $L$. reuteri strains. The different levels of reuterin production $(12.58,13.65$ and $21.08 \mathrm{mg} / \mathrm{mL}$ ) could also correlate well with the differences in the glycerol utilization (18.06 20.77 and $24.00 \mathrm{mg} / \mathrm{mL}$ ) of L. reuteri LR49, LR11 and LR47, respectively. Other research groups have reported reuterin production in the range of 45.7 to $298 \mathrm{mM}(30,41,42)$. However, most of these studies have used different $L$. reuteri strains and conditions, and also E. coli system to stimulate reuterin production. In contrast, we carried out a direct assay in MRS-Gly broth for reuterin production and obtained quite significant reuterin 


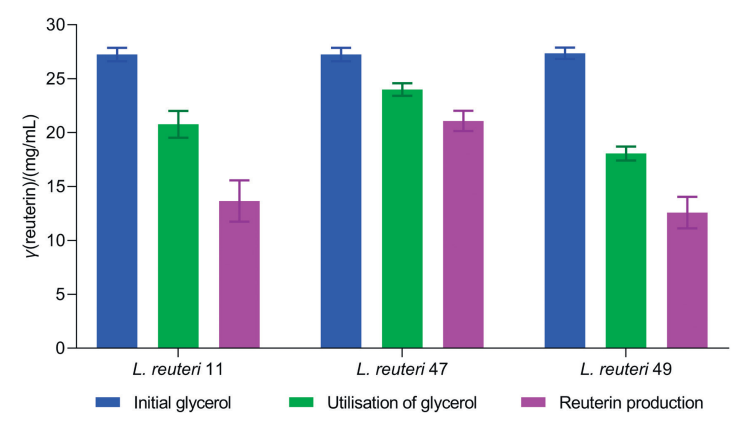

Fig. 2. Comparison of reuterin production among three selected Lactobacillus reuteri strains. Reuterin was produced by $L$. reuteri strains LR11, LR47 and LR49 in glycerol solution using a two-step fermentation process. Reuterin concentrations were determined using a modified colourimetric method and compared against the concentrations of glycerol remaining in the solution to yield a percentage of glycerol converted to reuterin. The blue bars represent initial glycerol concentration, green bars represent utilisation of glycerol during reuterin production, and the purple bars indicate the reuterin production from the utilised glycerol. L. reuteri 47 strain indicates that the amount of produced reuterin is significantly different $(p<0.05)$ than the amounts produced by other strains

concentrations without any external stimulation. This process can be particularly useful in in situ biopreservation of food where antimicrobial production is required. Nevertheless, the E. coli system could also be tested here to achieve a still higher reuterin concentrations in L. reuteri LR47 strain.

\section{Effect of reuterin and bacteriocin treatments on raw milk shelf-life}

Based on the literature survey on reuterin and bacteriocins $(11-13,17,24,26,29)$, current work was undertaken to investigate the effect of different concentrations of reuterin, nisin and pediocin individually or in different combinations on the shelf-life of raw milk. Literature search indicates that there are hardly any studies conducted on the preservation of raw milk using reuterin and bacteriocins. Thus, we proceeded to experiment and verify if different combinations of these antimicrobial compounds would be effective in controlling the initial microbial counts without compromising the physiochemical properties of raw milk. The selected concentrations of reuterin, nisin and pediocin were based on the earlier studies $(11,17,29)$ and total plate count (TPC), coliform count, $\mathrm{pH}$ and titratable acidity (TA) were measured to monitor microbial progression at $0,3,6$ and $9 \mathrm{~h}$ of incubation at $37^{\circ} \mathrm{C}$. Raw milk samples were significantly influenced by the type of antimicrobial combination in the treatments and the duration of incubation at $37^{\circ} \mathrm{C}$ (shown in Fig. 3 and Fig. 4, Table S1 and Table S2).

In the first subgroup, reuterin, nisin and pediocin were added singly to each raw milk sample and physicochemical parameters were measured. At the beginning of the incubation period $(0 \mathrm{~h})$, the overall TPC and coliform count was 4.6 and $4.1 \log \mathrm{CFU} / \mathrm{mL}$, respectively, in all raw milk samples. However, after the initial 3-hour incubation, there was a)

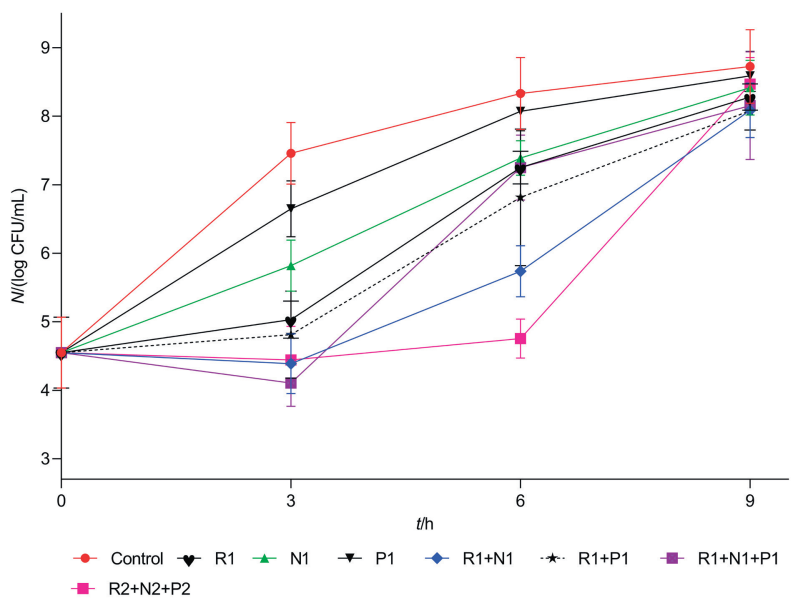

b)

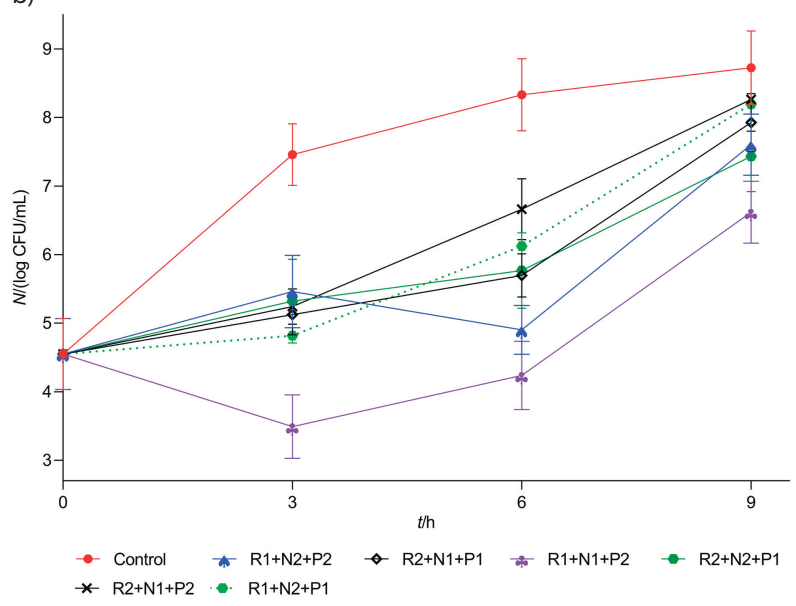

Fig. 3. Inhibitory activity of different biopreservative treatments on total plate count (TPC) (log CFU/mL) of raw milk at different time intervals at $37^{\circ} \mathrm{C}$ : a) when treated with first and b) second set of biopreservatives (reuterin (R), nisin $(N)$ and pediocin $(P)$ ). Results are shown as mean values \pm standard deviations (S.D.) of three samples taken from three replicate experiments $(N=9)$. Sample abbreviations are given in Table 1

a significant increase in the TPC and coliform count in the control sample. The addition of reuterin, nisin and pediocin showed an initial bacteriostatic effect, having respective TPC and coliform count of 2.4, 1.6 and $0.7 \mathrm{log}$ CFU/mL and 1.1, 1.5 and $0.4 \log$ CFU/mL (Fig. 3a and Fig. 4a), which was lower than control sample count (Table S1 and Table S2). After further 3-hour incubation (i.e. total $6 \mathrm{~h}$ of incubation), the TPC and coliform count continued to increase in the control sample, as well as in the treated samples, but they remained lower than in the control. After $9 \mathrm{~h}$ of incubation, the antibacterial action of the three added biopreservatives seemed to have been exhausted and very low bacterial inhibition was visible in the treated samples. Earlier, El-Ziney and Debevere (45) and Arqués et al. (24), who studied the efficacy of reuterin in UHT skimmed milk at 7 or $37^{\circ} \mathrm{C}$, had shown that reuterin had a bacteriostatic effect against individual Gram-negative 
a)

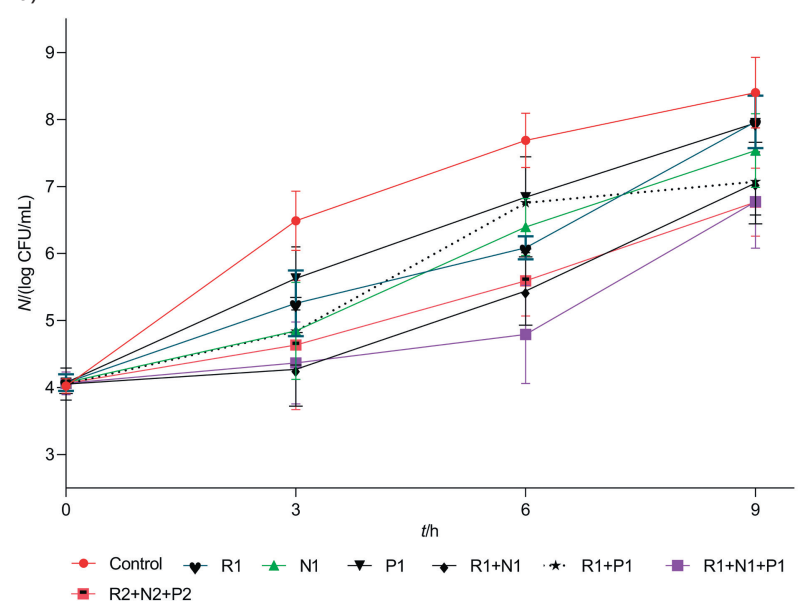

b)

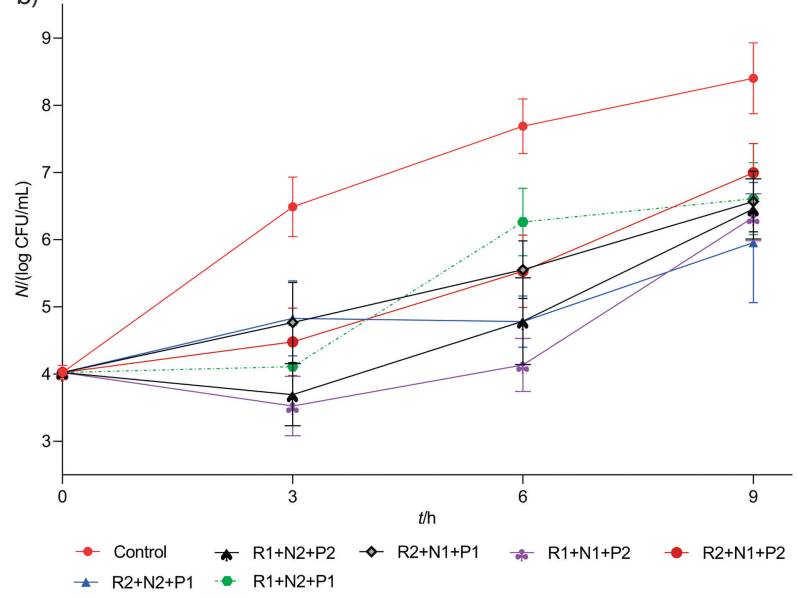

Fig. 4. Inhibitory activity of different biopreservative treatments on coliform count (log CFU/mL) of raw milk at different time intervals at $37^{\circ} \mathrm{C}: \mathrm{a}$ ) when treated with first and b) second set of biopreservatives (reuterin $(\mathrm{R})$, nisin $(\mathrm{N})$ and pediocin $(\mathrm{P})$ ). Results are shown as mean values \pm standard deviations (S.D.) of three samples taken from three replicate experiments $(N=9)$. Sample abbreviations are given in Table 1

bacteria. However, it was also observed that reuterin enacted strong inhibitory action against other pathogens and inhibition of up to 4 log units could be attained, but at a lower temperature of $7^{\circ} \mathrm{C}$. Arqués et al. (11) in another study showed that when added singly, nisin exhibited bactericidal effect against $\mathrm{S}$. aureus at $37^{\circ} \mathrm{C}$ during $4 \mathrm{~h}$ of incubation. However, the pathogen regained its growth after reaching bacterial counts similar to that in control milk after $24 \mathrm{~h}$. Hence, it is quite clear that individual antimicrobial metabolites have limited capacity against bacterial targets in the milk system. Inhibitory effect can be more suppressed when mixed microflora in ambient conditions are used, like in this study. Hence, the different combinations of reuterin, nisin and pediocin were further tested to achieve better results.

In the second subgroup, a combination of two antimicrobial compounds was used. A greater initial inhibition of TPC and coliform count was observed than when these antimicrobial compounds were applied individually in raw milk system. After $3 \mathrm{~h}$, the raw milk treated with $150 \mathrm{AU} / \mathrm{mL}$ reuterin and $100 \mathrm{IU} / \mathrm{mL}$ nisin $(\mathrm{R} 1+\mathrm{N} 1)$, and $150 \mathrm{AU} / \mathrm{mL}$ reuterin and $2185 \mathrm{AU} / \mathrm{mL}$ pediocin (R1+P1) had TPC and coliform counts of 3.2 and $2.2 \mathrm{log} C F U / \mathrm{mL}$ and 2.6, $1.5 \mathrm{log} C F U / \mathrm{mL}$ respectively, which was lower than the control sample (Fig. $3 a$ and Fig. 4a). However, at the end of $6 \mathrm{~h}$ of incubation, the initial inhibitory effect of the combination started diminishing and there was a steady increase in the TPC and coliform count in the samples treated with both combinations. Thereafter, the growth resumed in the two samples after $9 \mathrm{~h}$ of incubation and the TPC and coliform bacteria reached counts that were comparable with those in the control sample. The initial reduction in the bacterial counts was synergistic because the combined effect of two treatments was greater than the sum of individual inhibition treatments. However, some researchers have reported that the combined effect of reuterin with nisin could not improve the antimicrobial efficacy of reuterin against Gram-negative bacteria in UHT skimmed milk at 4 or $8{ }^{\circ} \mathrm{C}$, although they also reported that reuterin in combination with nisin had a synergistic effect against $L$. monocytogenes in milk at $37^{\circ} \mathrm{C}$ (25). Arqués et al. (26) also reported a synergistic effect of reuterin $(8 \mathrm{AU} / \mathrm{mL})$ with nisin $(100 \mathrm{IU} / \mathrm{mL})$ against $L$. monocytogenes and $S$. aureus in milk at $37^{\circ} \mathrm{C}$. The reuterin activity against $L$. monocytogenes has also been reported to be enhanced by the addition of $3 \%$ salt (45). Hence, the results of the current study confirm the synergistic action of reuterin and nisin against the raw milk microflora. In addition, a combination of nisin and pediocin PA-1 also showed a strong synergistic bactericidal activity against milk pathogens (46). However, the dual combination was not effective enough to obtain a sufficient level of shelf-life extension of raw milk at $37^{\circ} \mathrm{C}$, hence, triple combinations were further tested.

In the third subgroup with the combination of three biopreservatives at different concentrations, the treatment with $150 \mathrm{AU} / \mathrm{mL}$ reuterin, $100 \mathrm{IU} / \mathrm{mL}$ nisin and $600 \mathrm{AU} / \mathrm{mL}$ pediocin $(\mathrm{R} 1+\mathrm{N} 1+\mathrm{P} 2)$ showed the best results and had a significant effect on the TPC and coliform count. After $3 \mathrm{~h}$ of incubation, the TPC and coliform count were 3.9 and $2.9 \log$ CFU/mL respectively, which is lower than in the control milk (Fig. $3 \mathrm{~b}$ and Fig. 4b). The efficacy of $150 \mathrm{AU} / \mathrm{mL}$ reuterin, $100 \mathrm{IU} / \mathrm{mL}$ nisin and $600 \mathrm{AU} / \mathrm{mL}$ pediocin $(\mathrm{R} 1+\mathrm{N} 1+\mathrm{P} 2)$ treatment was maintained even after $6 \mathrm{~h}$ of incubation and very minimal increase in the TPC and coliform count was observed. The effect, however, seemed to fade thereafter and increase in both TPC and coliform count could be observed (Fig. 3b and Fig. 4b). As anticipated, the triple combination of antimicrobial compounds showed the best effect, which could be attributed to a synergistic action among the used antimicrobials. Arqués et al. (11) had shown earlier that a similar triple combination consisting of three biopreservatives reuterin, nisin and lactoperoxidase system (LPS) in curdled milk had a very strong synergistic bactericidal effect against $L$. monocytogenes with only $0.3 \log$ CFU/mL bacterial count remaining in the milk samples compared to control (8.3 log CFU/mL). In compliance with 
our obtained results, they also reported that the combination of three biopreservatives comprising both reuterin and nisin along with LPS system exhibited superior action to single or a combination of two biopreservatives in milk system.

Efficacy of biopreservatives used in triple combinations is evident in the $\mathrm{pH}$ and acidity of the treated raw milk samples. Among different combinations of biopreservatives, only the treatment with $\mathrm{R} 1+\mathrm{N} 1+\mathrm{P} 2$ combination was able to maintain TA of $0.22 \%$ lactic acid (Fig. 5) and $\mathrm{pH}=6.43$ (Fig. 6) after $6 \mathrm{~h}$ of incubation, which was within the commercially acceptable range of $\mathrm{pH}=6.22-6.77$ and TA of $0.16-0.25 \%$ lactic acid (47), while after all the other treatments higher $\mathrm{pH}$ and TA values exceeded their commercially acceptable limits (Fig. 5 and Fig. 6). Under the prevailing tropical conditions, the major bacterial spoilage encountered in raw milk is curdling, which is mainly due to the increase in titratable acidity and decrease of $\mathrm{pH}$. The commercial dairy industry also uses TA values to judge the freshness of raw milk as a basis for its overall

a)

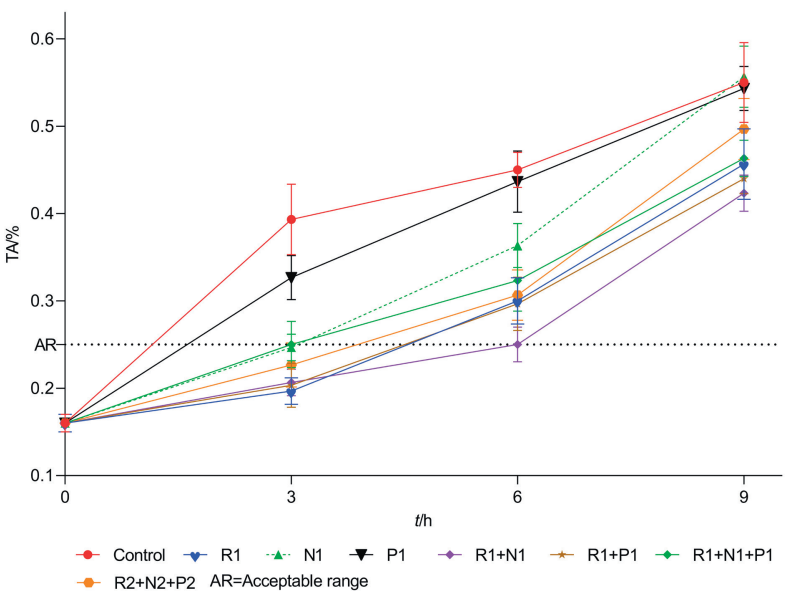

b)

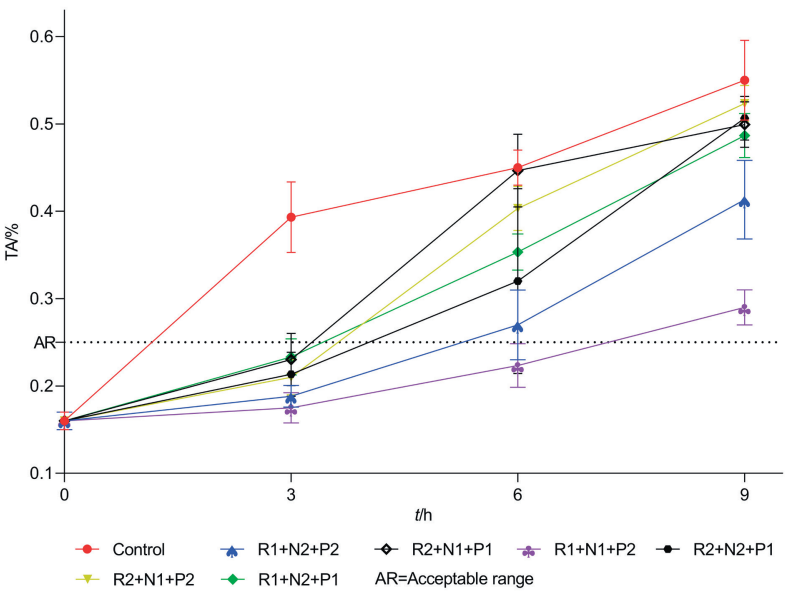

Fig. 5. Change in titratable acidity (TA) of raw milk after different biopreservative (reuterin (R), nisin (N) and pediocin (P)) treatments at different time intervals at $37^{\circ} \mathrm{C}$ : a) with first and b) second set of biopreservatives. Results are shown as mean values \pm standard deviations (S.D.) of three samples taken from three replicate experiments $(N=9)$. Sample abbreviations are given in Table 1 acceptability for further processing. The rise in TA values is a direct indicator of microbiological activity in milk, which is more rapid at ambient temperatures (48). Apart from various other microbial groups, the LAB groups and coliforms are the most active in the initial increase in the TA of raw milk. Bacteriocins used in the study such as nisin and pediocin are derived from $L A B$ groups and are active against closely related species (15). Therefore, bacteriocins used in the study may have played an important role in controlling the LAB groups. However, bacteriocins are not very effective against Gram-negative bacteria such as coliforms, Pseudomonas and other similar bacteria that are prevalent in raw milk. Hence, the reuterin system may have worked in parallel to inhibit and suppress the growth of these groups of bacteria in the raw milk and extend the shelf-life of raw milk for a period of $6 \mathrm{~h}$ at $37^{\circ} \mathrm{C}(\mathrm{Ta}$ ble S3 and Table S4). The reuterin system works by inducing oxidative stress in target cells (44), while both bacteriocins typically act by forming pores in the bacterial cell membrane.

a)

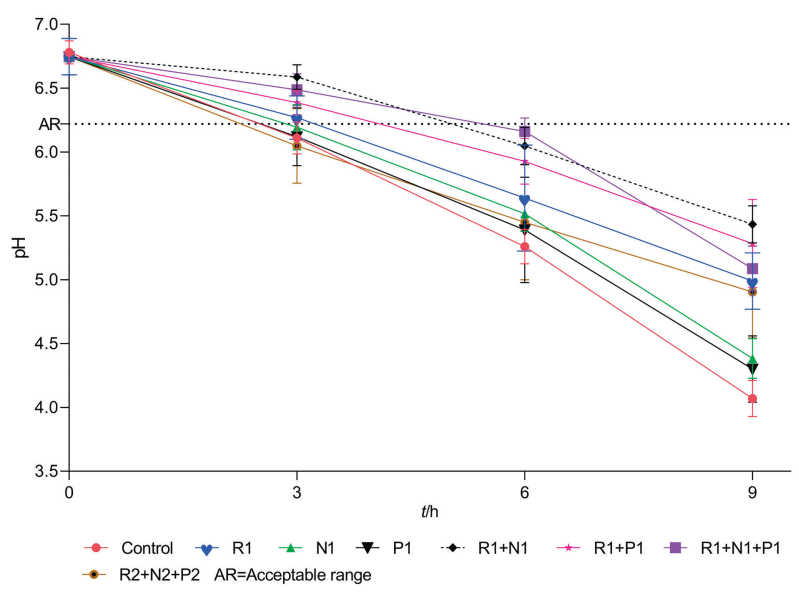

b)

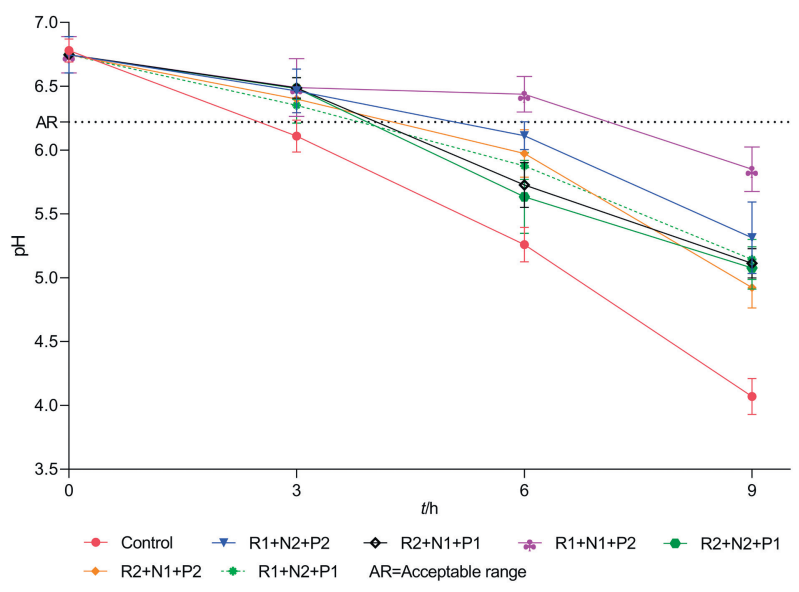

Fig. 6. Change in the $\mathrm{pH}$ of raw milk after different biopreservative (reuterin (R), nisin $(\mathrm{N})$ and pediocin $(\mathrm{P})$ ) treatments at different time intervals at $37^{\circ} \mathrm{C}$ : a) when treated with first and b) second set of biopreservatives. Results are shown as mean values \pm standard deviations (S.D.) of three samples taken from three replicate experiments $(N=9)$. Sample abbreviations are given in Table 1 
This multitarget system could also explain the increased efficacy and synergistic action of the triple combination of biopreservatives in raw milk system. Thus, our results show that reuterin could be successfully combined with nisin and pediocin at specific concentrations and used to inhibit complex microflora that is prevalent in raw milk and maintain it for at least $6 \mathrm{~h}$ under ambient temperature conditions.

\section{CONCLUSIONS}

Current study was initiated to prevent spoilage of raw milk as heavy microbial contamination of raw milk at the farm level is the major reason of milk spoilage under the prevailing tropical conditions. In the absence of suitable technological interventions, the use of natural biopreservatives, viz. lactic acid bacteria (LAB) and their metabolites, can offer a suitable solution to address this problem. During the course of the study, Lactobacillus reuteri strain LR47 was characterized for its antimicrobial activity, presence of reuterin-producing genes, and its capability to produce reuterin, a potent wide-spectrum antimicrobial metabolite, was confirmed. Finally, the ability of reuterin-containing cell-free supernatants from L. reuteri LR47 in conjunction with bacteriocins to enhance the shelf-life of raw milk under ambient conditions was tested. The results show that a combination of specific concentrations of reuterin, nisin and pediocin could effectively control the initial microbial load in raw milk and prolong the shelf-life up to $6 \mathrm{~h}$ at $37^{\circ} \mathrm{C}$, while maintaining the physicochemical parameters, viz. acidity and $\mathrm{pH}$, within the commercially acceptable range. The study is the first of its kind to demonstrate that wide-spectrum antimicrobial metabolite(s) from $L A B$ have a great potential to improve and maintain the quality and shelf-life of raw milk at farm level and minimize economic losses to milk farmers and dairy industry sector. Further studies may be required to optimize the use of reuterin for extending the shelf-life of raw milk beyond $6 \mathrm{~h}$ and establish its safety and efficacy as a biopreservative. If successful, this approach could be a first line of milk preservation at farm level even before undergoing any thermal/radiation or extended shelf-life processing or entering the cold chain.

\section{ACKNOWLEDGEMENT}

The authors duly acknowledge the Director, ICAR-National Dairy Research Institute, Karnal, Haryana, India, for providing all the necessary facilities for carrying out the present work.

\section{CONFLICT OF INTEREST}

The authors declare that they have no competing interests.

\section{SUPPLEMENTARY MATERIALS}

All supplementary materials are available at: www.ftb. com.hr.

\section{AUTHORS' CONTRIBUTION}

N. Kumar participated in the work conception, designing, carrying out all the experimental work, data analyses and interpretation, and writing of the manuscript. V. Kumar was involved in data analyses. S. M. Waheed was involved in data analyses and interpretation, manuscript writing, editing and finalising. D. Pradhan conceived, planned, designed, and supervised the entire work, contributed to writing and finalising the manuscript. All authors have read and approved the final manuscript.

\section{ORCID ID}

N. Kumar $\odot$ https://orcid.org/0000-0003-0425-1707

V. Kumar (10 https://orcid.org/0000-0002-0461-6991

S. M. Waheed (1) https://orcid.org/0000-0001-7068-0388

D. Pradhan (1) https://orcid.org/0000-0002-9174-6056

\section{REFERENCES}

1. Kalkwarf HJ, Khoury JC, Lanphear BP. Milk intake during childhood and adolescence, adult bone density, and osteoporotic fracture in US women. Am J Clin Nutr. 2003;77(1):257-65.

https://doi.org/10.1093/ajcn/77.1.257

2. Nsofor ON, Frank JF. Milk and dairy products. In: Doyle MP, Beuchat LR, Montville TJ, editors. Food microbiology: Fundamentals and frontiers. Washington DC, USA: ASM Press; 2013. pp. 169-217.

3. Hayes MC, Ralyea RD, Murphy SC, Carey NR, Scarlett JM, Boor KJ. Identification and characterization of elevated microbial counts in bulk tank raw milk. J Dairy Sci. 2001;84(1):292-8.

https://doi.org/10.3168/jds.S0022-0302(01)74479-7

4. Derakhshani H, Fehr KB, Sepehri S, Francoz D, De Buck J, Barkema HW, et al. Invited review: Microbiota of the bovine udder: contributing factors and potential implications for udder health and mastitis susceptibility. J Dairy Sci. 2018;101(12):10605-25. https://doi.org/10.3168/jds.2018-14860

5. Vacheyrou M, Normand AC, Guyot P, Cassagne C, Piarroux $\mathrm{R}$, Bouton $\mathrm{Y}$. Cultivable microbial communities in raw cow milk and potential transfers from stables of sixteen French farms. Int J Food Microbiol. 2011;146(3):253-62.

https://doi.org/10.1016/j.ijfoodmicro.2011.02.033

6. Claeys WL, Cardoen S, Daube G, De Block J, Dewettinck K, Dierick K, et al. Raw or heated cow milk consumption: Review of risks and benefits. Food Control. 2013;31(1):251-62. https://doi.org/10.1016/j.foodcont.2012.09.035

7. WHO estimates of the global burden of foodborne diseases. Foodborne Disease Burden Epidemiology Reference Group 2007-2015. Geneva, Switzerland: World Health Organization; 2015. Available from: https://apps.who.int/iris/ 
bitstream/handle/10665/199350/9789241565165_eng.pd$f$ ?sequence $=1$.

8. Bille PG, Haradoeb BR, Shigwedha N. Evaluation of chemical and bacteriological quality of raw milk from Neudamm dairy farm in Namibia. African J Food Agric Nutr Dev. 2009;9(7):1511-23.

https://doi.org/10.4314/ajfand.v9i7.47682

9. Kourous G, Wossenyeleh H. Over $\$ 90$ million worth of milk lost each year in East Africa and the Near East. FAO Newsroom. Rome, Italy: Food and Agriculture Organization of the United Nations (FAO); 2004. Available from:

http://www.fao.org/newsroom/en/news/2004/51147/index.html.

10. Buzby JC, Wells HF, Hyman J. The estimated amount, value, and calories of postharvest food losses at the retail and consumer levels in the United States. Economic Information Bulletin No. 121; 2014. Available from: https://www.ers. usda.gov/webdocs/publications/43833/43680_eib121.pdf.

11. Arqués JL, Rodríguez E, Nuñez M, Medina M. Antimicrobial activity of nisin, reuterin, and the lactoperoxidase system on Listeria monocytogenes and Staphylococcus aureus in cuajada, a semisolid dairy product manufactured in Spain. J Dairy Sci. 2008;91(1):70-5.

https://doi.org/10.3168/jds.2007-0133

12. Silva CCG, Silva SPM, Ribeiro SC. Application of bacteriocins and protective cultures in dairy food preservation. Front Microbiol. 2018;9:594.

https://doi.org/10.3389/fmicb.2018.00594

13. Chen $\mathrm{H}$, Hoover DG. Bacteriocins and their food applications. Compr Rev Food Sci Food Saf. 2003;2(3):82-100. https://doi.org/10.1111/j.1541-4337.2003.tb00016.x

14. Garsa AK, Kumariya R, Kumar A, Lather P, Kapila S, Sood $S$. Industrial cheese whey utilization for enhanced production of purified pediocin PA-1. LWT - Food Sci Technol. 2014;59(2):656-65.

https://doi.org/10.1016/j.lwt.2014.07.008

15. Goyal C, Malik RK. Pradhan D. Purification and characterization of a broad spectrum bacteriocin produced by a selected Lactococcus lactis strain 63 isolated from Indian dairy products. J Food Sci Technol. 2018;55(9):3683-92.

https://doi.org/10.1007/s13197-018-3298-4

16. O'Sullivan L, Ryan MP, Ross RP, Hill C. Generation of foodgrade lactococcal starters which produce the lantibiotics lacticin 3147 and lacticin 481. Appl Environ Microbiol. 2003;69(6):3681-5. https://doi.org/10.1128/AEM.69.6.3681-3685.2003

17. Kozáková D, Holubová J, Plocková M, Chumchalová J, Čurda L. Impedance measurement of growth of lactic acid bacteria in the presence of nisin and lysozyme. Eur Food Res Technol. 2005;221:774-8.

https://doi.org/10.1007/s00217-005-0026-x
18. Casas IA, Dobrogosz WJ. Validation of the probiotic concept: Lactobacillus reuteri confers broad-spectrum protection against disease in humans and animals. Microb Ecol Health Dis. 2000;12(4):247-85.

https://doi.org/10.1080/08910600050216246-1

19. Mu Q, Tavella VJ, Luo XM. Role of Lactobacillus reuteri in human health and diseases. Front Microbiol. 2018;9:757.

https://doi.org/10.3389/fmicb.2018.00757

20. Vollenweider S, Lacroix C. 3-Hydroxypropionaldehyde: Applications and perspectives of biotechnological production. Appl Microbiol Biotechnol. 2004;64(1):16-27. https://doi.org/10.1007/s00253-003-1497-y

21. Axelsson LT, Chung TC, Dobrogosz WJ, Lindgren SE. Production of a broad spectrum antimicrobial substance by Lactobacillus reuteri. Microb Ecol Health Dis. 1989;2(2):131-6. https://doi.org/10.3109/08910608909140210

22. Siedler S, Balti R, Neves AR. Bioprotective mechanisms of lactic acid bacteria against fungal spoilage of food. Curr Opin Biotechnol. 2019;56:138-46.

https://doi.org/10.1016/j.copbio.2018.11.015

23. Naidu AS, editor. Natural food antimicrobial systems. Boca Raton, FL, USA: CRC Press; 2000. pp. 567-88. Available from: https://www.routledge.com/Natural-Food-Antimicrobial-Systems/Naidu/p/book/9780367398453

24. Arqués JL, Rodríguez E, Nuñez M, Medina M. Combined effect of reuterin and lactic acid bacteria bacteriocins on the inactivation of food-borne pathogens in milk. Food Control. 2011;22(3-4):457-46.

https://doi.org/10.1016/j.foodcont.2010.09.027

25. Arqués JL, Rodríguez E, Nuñez M, Medina M. Inactivation of Gram-negative pathogens in refrigerated milk by reuterin in combination with nisin or the lactoperoxidase system. Eur Food Res Technol. 2008;227(1):77-82.

https://doi.org/10.1007/s00217-007-0695-8

26. Arqués JL, Fernández J, Gaya $P$, Nuñez $M$, Rodríguez E, Medina M. Antimicrobial activity of reuterin in combination with nisin against food-borne pathogens. Int J Food Microbiol. 2004;95(2):225-9.

https://doi.org/10.1016/j.ijfoodmicro.2004.03.009

27. Mansour M, Amri D, Bouttefroy A, Linder M, Milliere JB. Inhibition of Bacillus licheniformis spore growth in milk by nisin, monolaurin, and pH combinations. J Appl Microbiol. 1999;86(2):311-24.

https://doi.org/10.1046/j.1365-2672.1999.00669.x

28. Mansour M, Millière JB. An inhibitory synergistic effect of a nisin-monolaurin combination on Bacillus sp. vegetative cells in milk. Food Microbiol. 2001;18(1):87-94.

https://doi.org/10.1006/fmic.2000.0379

29. Boussouel N, Mathieu F, Benoit V, Linder M, Revol-Junelles AM, Millière JB. Response surface methodology, an approach to predict the effects of a lactoperoxidase system, 
nisin, alone or in combination, on Listeria monocytogenes in skim milk. J Appl Microbiol. 1999;86(4):642-52. https://doi.org/10.1046/j.1365-2672.1999.00707.x

30. Pradhan D, Kumar N, Singh P, Gujjar P. Antagonistic activity of Lactobacillus reuteri strains isolated from different niches against food bacteria and its biopreservative application along with nisin in milk system. Indian J Dairy Sci. 2019;72(5):489-98.

https://doi.org/10.33785/IJDS.2019.v72i05.005

31. Lüthi-Peng Q, Dileme F, Puhan Z. Effect of glucose on glycerol bioconversion by Lactobacillus reuteri. Appl Microbiol Biotechnol. 2002;59(2-3):289-96.

https://doi.org/10.1007/s00253-002-1002-z

32. Toba T, Samant SK, Yoshioka E, Itoh T. Reutericin 6, a new bacteriocin produced by Lactobacillus reuteri LA 6. Lett Appl Microbiol. 1991;13(6):281-6. https://doi.org/10.1111/j.1472-765X.1991.tb00629.x

33. Versalovic J, Koeuth T, Lupski R. Distribution of repetitive DNA sequences in eubacteria and application to fingerprinting of bacterial genomes. Nucleic Acids Res. 1991;19(24):6823-31.

https://doi.org/10.1093/nar/19.24.6823

34. Walter J. Ecological role of lactobacilli in the gastrointestinal tract: Implications for fundamental and biomedical research. Appl Environ Microbiol. 2008;74(16):4985-4996. https://doi.org/10.1128/AEM.00753-08

35. Spagnolo F. Spectrophotometric determination of glycerol as sodium-cupri-glycerol complex. Anal Chem. 1953;25(10):1566-8.

https://doi.org/10.1021/ac60082a049

36. Chung TC, Axelsson L, Lindgren SE, Dobrogosz WJ. In vitro studies on reuterin synthesis by Lactobacillus reuteri. Microb Ecol Health Dis. 1989;2(2):137-44.

https://doi.org/10.3109/08910608909140211

37. Pradhan D, Goyal C, Malik R, Narsaiah K. Efficacy of alginate: Nanoliposome encapsulated pediocin against $L$. innocua in milk system. Int J Chem Studies. 2018;6(1):1371-6.

38. Kaur G, Singh TP, Malik RK. Antibacterial efficacy of nisin, pediocin 34 and enterocin FH99 against Listeria monocytogenes and cross resistance of its bacteriocin resistant variants to common food preservatives. Braz J Microbiol. 2013;44(1);63-71.

https://doi.org/10.1590/S1517-83822013005000025

39. AOAC Official Methods of Analysis. Arlington, VA, USA: AOAC International; 2005. Available from:

https://law.resource.org/pub/us/cfr/ibr/002/aoac.methods.1.1990.pdf.
40. GraphPad Prism, v. 8.1.2 for Windows, San Diego, CA, USA; 2018. Available from:

https://www.graphpad.com/scientific-software/prism/.

41. Spinler JK, Taweechotipatr M, Rognerud CL, Ou CN, Tumwasorn S, Versalovic J. Human-derived probiotic Lactobacillus reuteri demonstrate antimicrobial activities targeting diverse enteric bacterial pathogens. Anaerobe. 2008;14(3):166-71.

https://doi.org/10.1016/j.anaerobe.2008.02.001

42. Garde S, Gómez-Torres N, Delgado D, Gaya P, Ávila M. Influence of reuterin-producing Lactobacillus reuteri coupled with glycerol on biochemical, physical and sensory properties of semi-hard ewe milk cheese. Food Res Int. 2016;90:177-85.

https://doi.org/10.1016/j.foodres.2016.10.046

43. Daniel R, Bobik TA, Gottschalk G. Biochemistry of coenzyme $B_{12}$-dependent glycerol and diol dehydratases and organization of the encoding genes. FEMS Microbiol Rev. 1998;22(5):553-66.

https://doi.org/10.1111/j.1574-6976.1998.tb00387.x

44. Schaefer L, Auchtung TA, Hermans KE, Whitehead D, Borhan $\mathrm{B}$, Britton RA. The antimicrobial compound reuterin (3-hydroxypropionaldehyde) induces oxidative stress via interaction with thiol groups. Microbiology. 2010;156(6):158999.

https://doi.org/10.1099/mic.0.035642-0

45. el-Ziney MG, Debevere JM. The effect of reuterin on Listeria monocytogenes and Escherichia coli O157:H7 in milk and cottage cheese. J Food Prot. 1998;61(10):1275-80. https://doi.org/10.4315/0362-028X-61.10.1275

46. Zapico P, Medina M, Gaya P, Nuñez M. Synergistic effect of nisin and the lactoperoxidase system on Listeria monocytogenes in skim milk. Int J Food Microbiol. 1998;40(1-2):3542.

https://doi.org/10.1016/S0168-1605(98)00008-7

47. Neville MC, Jensen RG. The physical properties of human and bovine milks. In: Jensen RG, editor. Handbook of milk composition. San Diego, CA, USA: Academic Press; 1995. pp. 81-5.

https://doi.org/10.1016/B978-012384430-9/50008-1

48. Gwandu SH, Nonga HE, Mdegela RH, Katakweba AS, Suleiman TS, Ryoba R. Assessment of raw cow milk quality in smallholder dairy farms in Pemba Island Zanzibar, Tanzania. Vet Med Int. 2018;2018:Article ID: 1031726.

https://doi.org/10.1155/2018/1031726 